\title{
Oceanographic Effects On The Quantity And Quality Of Carrageenan From Seaweed Kappaphycus striatum Cultivated Using Longline Method in Mamuju Regency, West Sulawesi, Indonesia
}

\author{
Abdul Rahman Hamzah ${ }^{1) *}$, Mahatma Lanuru ${ }^{2)}$, Syafiuddin ${ }^{2)}$ \\ 1) Magister Program, Integrated Coastal Resource Management, Faculty of Marine Sciences and Fisheries, Hasanuddin University ${ }^{2)}$ \\ Faculty of Marine Sciences and Fisheries, Hasanuddin University, Makassar, Indonesia \\ E-mail: abrahamzah13@gmail.com \\ DOI: 10.29322/IJSRP.11.10.2021.p11862 \\ http://dx.doi.org/10.29322/IJSRP.11.10.2021.p11862
}

\begin{abstract}
Abstrack
Kappphycus striatum is one of the carrageenan-producing seaweeds. Seaweed cultivation is increasing along with the increasing use of carrageenan. In general, carrageenan is used in the food, cosmetic and pharmaceutical industries. Furthermore, the carrageenan content of seaweed is strongly influenced by the oceanographic conditions in which the seaweed is cultivated. Measurement of the quantity of carrageenan yielded a value of $43.50-80.63 \%$ with an average of $63.62 \% \pm 12.54$. The quantity of seaweed is affected by turbidity, phosphate, current velocity and temperature. The moisture content is $9.75 \%-24.91 \%$. with an average of $18.87 \% \pm 4.73$, influenced by $\mathrm{pH}$, turbidity, current velocity, temperature. While the ash content is $24.67-36.05$ with an average of $27.89 \pm 3.94$, influenced by dissolved oxygen and salinity.
\end{abstract}

Keywords: Kappaphycus striatum, Carrageenan, Seaweed, Oceanographic effects

\section{Intoduction}

Carrageenan-producing seaweed is a marine product that is widely cultivated by coastal communities in Indonesia (Manuhara et al., 2016), including in Mamuju Regency, West Sulawesi Province. This is because seaweed cultivation uses a fairly simple cultivation technology, does not require large capital, is a very profitable business, can be carried out in bulk, the maintenance period is relatively short, demand continues to increase, can absorb labor, and has a variety of processed products. (Rahadiati et al., 2012). Commonly cultivated species are Kappahycus alvarezii and Kappaphycus striatum (Hatta \& Yulianto, 1994).

In addition, seaweed has potential benefits through its carrageenan content where carrageenan is used in the food industry, cosmetics, medicines, pharmaceuticals, biofuels and fertilizers (Solorzano-chavez et al., 2019). Therefore, seaweed has become an internationally traded commodity (SIPPO, 2017)

Seaweed cultivation technology has undergone many changes and modifications according to the area and capabilities of the fishermen's business. The application of seaweed cultivation technology is currently dominated by the longline method (Parakkasi et al., 2020)

Seaweed cultivation using the longline method has also been developed in Mamuju Regency (Parakkasi et al., 2020). Mamuju Regency is located at $1^{0} 38^{\prime} 11^{0}$ ' $-2^{0} 54{ }^{\prime} 552^{\prime \prime}$ S $11^{0} 54$ ' 47' $-13^{0} 5^{\prime} 35^{\prime \prime}$ E. Mamuju Regency has a coastline of $275 \mathrm{Km}$, so that Mamuju Regency is one of the regencies in West Sulawesi Province that has the potential to develop marine aquaculture with economic value commodities such as seaweed (Sulbar, 2018). One of the development areas for seaweed cultivation in Mamuju Regency is Tadui Village.

The development of seaweed cultivation must pay attention to the relationship of oceanographic physical and chemical factors to the carrageenan content of seaweed because it can affect the carrageenan content (Effendi, 2003) (Ramdhan et al., 2018). Seaweed growth is influenced by $\mathrm{pH}$, salinity, light intensity, temperature and nutrients in the waters (Parenrengi \& Sulaeman, 2007); (Adipu et al., 2013); (Tee et al., 2015)

The purpose of this study was to determine the effect of oceanographic factors on the quantity of carrageenan (carrageenan content) and carrageenan quality (water content and ash content) cultivated in the waters of Tadui Village, Mamuju District, Mamuju Regency, West Sulawesi Province.

\section{Material and Method}

\subsection{Research Site}

This publication is licensed under Creative Commons Attribution CC BY.

http://dx.doi.org/10.29322/IJSRP.11.10.2021.p11862

WwW.ijsrp.org 
This research was conducted in January - February 2021 in Tadui Village, Mamuju District, Mamuju Regency, West Sulawesi Province. Water quality analysis was carried out at the Chemical Oceanography Laboratory, Faculty of Marine Sciences and Fisheries, Hasanuddin University, while the analysis of the quality and quantity of carrageenan was carried out at the Water Productivity and Quality Laboratory, Faculty of Marine Sciences and Fisheries, Hasanuddin University.

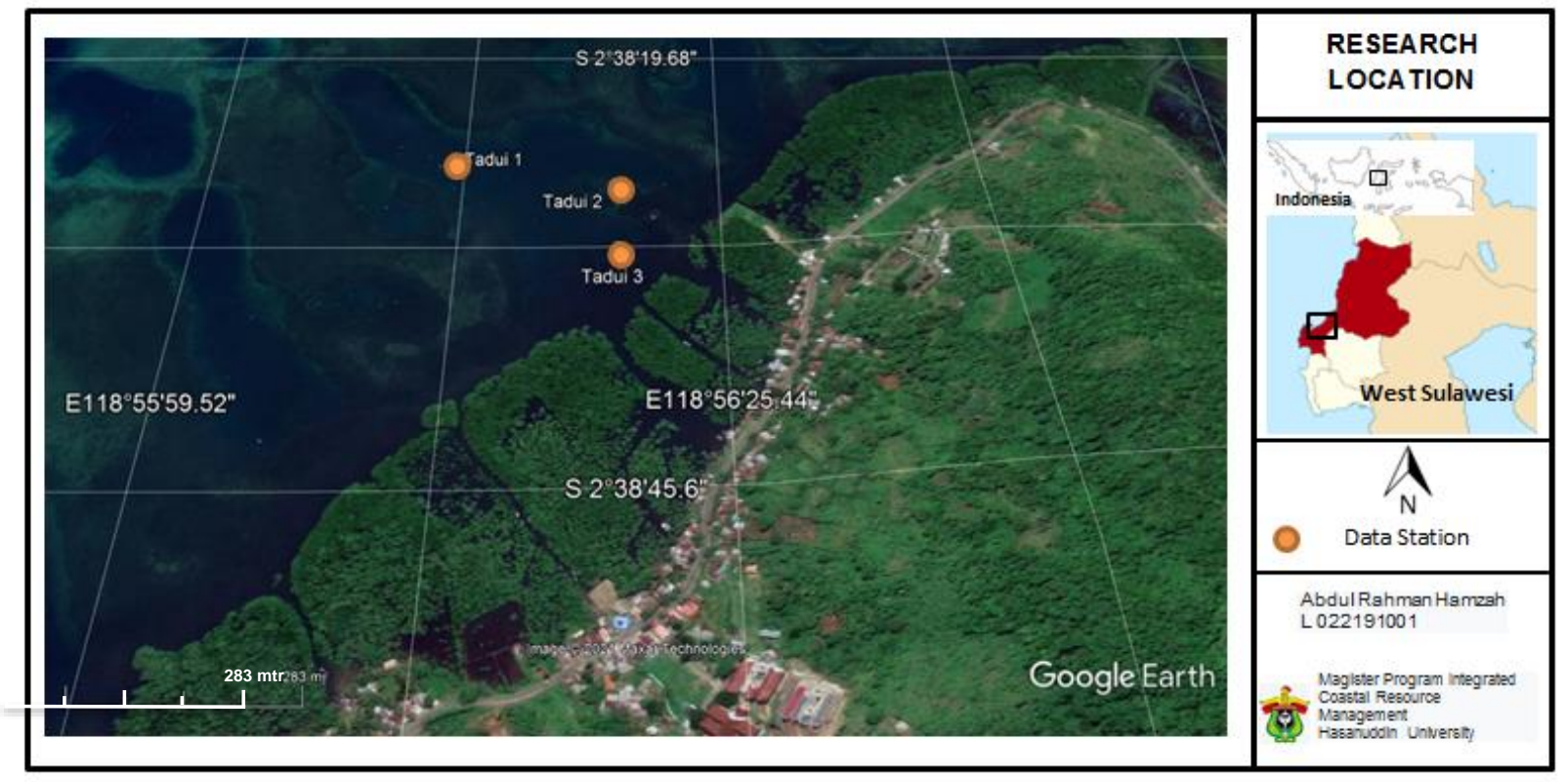

Figure 1.

Research location map

\subsection{Seaweed Cultivation}

The seaweed cultivation method used in this study is the longline method, which is a cultivation method using long ropes that are stretched in sea waters. The ropes used are PE (Polyethylene) ropes as planting ropes and raffia ropes as places to tie seaweed seeds. Seaweed is planted on Polyethylene No 4 stretch ropes with a length of $100-120 \mathrm{~m}$. The rope for the planting point uses raffia rope with a single planting point. The spacing of the planting points used in this study was $25 \mathrm{~cm}$. The initial weight of the seeds is 100 grams for each planting point. The seaweed cultivated in this study is Kappaphycus striatum variant Sacol. The seaweed seeds were taken from the waters of the Tadui Village, Mamuju District.

\subsection{Water Quality Monitoring}

Physical parameters of the waters of the research location were measured directly at the seaweed cultivation location every 10 (ten) days which included current velocity, temperature, and salinity. The chemical parameters of the waters, namely turbidity, $\mathrm{pH}$, phosphate, nitrate and dissolved oxygen, are also measured every 10 (ten) days by taking seawater samples taken and then frozen for further analysis in the laboratory.

\subsection{Carrageenan Quantity and Quality Test}

The seaweed that has been cultivated at the research site is then dried for carrageenan extraction based on the SNI $03-70-$ (1990) method. Furthermore, quantity and quality tests were carried out such as carragenan content, water content and ash content tests on the carrageenan extraction results.

\subsection{Data Analysis}

The relationship between the quality and quantity of carrageenan on oceanographic factors was analyzed using Pearson's Simple Linear Correlation Analysis. While the parameters of the aquatic environment that affect the quantity and quality of carrageenan will be analyzed by Principal Component Analysis (PCA). The software used is IBM SPSS Statistics 24.

\section{Results and Discussion}




\subsection{Oceanographic Parameters}

The $\mathrm{pH}$ value of the waters during the observation ranged from 7.65 to 7.73 (Table 1). The dynamics of the $\mathrm{pH}$ value in the water will affect the chemical reactions that occur in the waters. A low $\mathrm{pH}$ value will cause biochemical activities to slow down, if the $\mathrm{pH}$ value is higher it will stop biochemical activities (Lunning et al., 1990).

Table 1. The results of measuring oceanographic parameters

\begin{tabular}{|l|l|l|l|l|l|l|l|l|}
\hline $\begin{array}{l}\text { Measurement } \\
\text { Day }\end{array}$ & pH & $\begin{array}{l}\text { Turbidity } \\
(\mathbf{N T U})\end{array}$ & $\begin{array}{l}\text { Dissolved } \\
\text { oxygen } \\
(\mathbf{m g} / \mathbf{L})\end{array}$ & $\begin{array}{l}\text { Salinity } \\
(\mathbf{\%} / \mathbf{o o})\end{array}$ & $\begin{array}{l}\text { Current } \\
\text { velocity } \\
(\mathbf{c m} / \mathbf{s})\end{array}$ & $\begin{array}{l}\text { Temperature } \\
\left(\mathbf{}{ }^{\circ} \mathbf{C}\right)\end{array}$ & $\begin{array}{l}\text { Phophate } \\
(\mathbf{m g} / \mathbf{L})\end{array}$ & $\begin{array}{l}\text { Nitrate } \\
(\mathbf{m g} / \mathbf{L})\end{array}$ \\
\hline Day 0 & $7.72 \pm 0.026$ & $1.41 \pm 0.459$ & $5.59 \pm 0.187$ & $29.67 \pm 2.867$ & $0.07 \pm 0.015$ & $29.67 \pm 0.471$ & $0.03 \pm 0.008$ & $0.13 \pm 0.031$ \\
\hline Day 10 & $7.65 \pm 0.034$ & $1.02 \pm 0.029$ & $5.88 \pm 0.277$ & $28.33 \pm 3.091$ & $0.07 \pm 0.020$ & $29.33 \pm 0.471$ & $0.04 \pm 0.009$ & $0.12 \pm 0.009$ \\
\hline Day 20 & $7.70 \pm 0.071$ & $0.84 \pm 0.338$ & $6.30 \pm 0.333$ & $31.00 \pm 0.816$ & $0.07 \pm 0.012$ & $29.00 \pm 0.000$ & $0.04 \pm 0.009$ & $0.13 \pm 0.003$ \\
\hline Day 30 & $7.69 \pm 0.050$ & $1.43 \pm 0.184$ & $5.98 \pm 0.240$ & $30.67 \pm 0.471$ & $0.07 \pm 0.017$ & $29.67 \pm 0.471$ & $0.05 \pm 0.007$ & $0.12 \pm 0.023$ \\
\hline Day 39 & $7.73 \pm 0.031$ & $0.93 \pm 0.205$ & $6.01 \pm 0.622$ & $23.00 \pm 9.201$ & $0.09 \pm 0.015$ & $29.67 \pm 0.471$ & $0.04 \pm 0.005$ & $0.13 \pm 0.010$ \\
\hline
\end{tabular}

Average \pm Standard Deviation, $\mathrm{n}=3$

The $\mathrm{pH}$ value of the waters during the observation ranged from 7.65 to 7.73 (Table 1). The dynamics of the $\mathrm{pH}$ value in the water will affect the chemical reactions that occur in the waters. A low $\mathrm{pH}$ value will cause biochemical activities to slow down, if the $\mathrm{pH}$ value is higher it will stop biochemical activities (Lunning et al., 1990).

The turbidity of the waters varied from 0.84 to 1.43 NTU for 39 days of observation. The turbidity value is very suitable for seaweed growth, where the required value is < 10 (Aslan, 1998) and (Adipu et al., 2013)

Salinity at the cultivation sites observed ranged from $23.00 \%$ to $31.00 \%$. Seaweed is a marine organism that cannot tolerate a high salinity range (stenohaline) (Warsidah, 2020). Increasing and decreasing salinity above the optimum limit causes seaweed to break easily, lack elasticity, and its growth will be stunted

The current speed varies from $0.07 \mathrm{~cm} / \mathrm{s}$ to $0.09 \mathrm{~cm} / \mathrm{s}$. The speed of the current affects the seaweed because the seaweed will get nutrients through the flow of water that is created when the current movement occurs. The movement of the water will carry nutrients and at the same time wash the dirt that sticks to the seaweed thallus (Damayanti et al., 2019).

The temperature during the study ranged from 29.00 to $29.67{ }^{\circ} \mathrm{C}$. Temperature is very influential on increasing primary productivity in a waters (Rintaka et al., 2013). Temperature is known to affect several physiological functions that occur in seaweed including photosynthesis, respiration, metabolism, growth and reproduction (Ramdhan et al., 2018)

The phosphate content of the waters varies from $0.03 \mathrm{mg} / \mathrm{L}$ to $0.05 \mathrm{mg} / \mathrm{L}$. Phosphate plays an important role in ATPmediated energy transfer and other high-energy compounds present in photosynthesis and respiration. The abundance of phosphorus can stimulate the growth and rate of photosynthesis of some algae, as well as increase the production of carrageenan (Parenrengi et al., 2020).

Water nitrate recorded during the study was $0.12 \mathrm{mg} / \mathrm{L}$ to $0.13 \mathrm{mg} / \mathrm{L}$. Nitrates function in shoot formation, increase growth rate, formation of soluble proteins and affect the content of phycobiliprotein, nitrate, nitrite and amino acid content of the thallus, photosynthesis, enzyme activity involved in carbon metabolism, and nitrate reductase (Parenrengi et al., 2020)

Dissolved oxygen ranged from $5.59 \mathrm{mg} / \mathrm{L}$ to $6.30 \mathrm{mg} / \mathrm{L}$. Dissolved oxygen is a limiting factor for the existence of living organisms, so dissolved oxygen is a basic requirement for the life of living things in water. Dissolved oxygen will decrease with increasing depth. This is related to the vertical increase in temperature, light penetration, density, oxygen content and nutrients contained in the waters (Susilowati et al., 2012)

\subsection{Quantity and quality of carrageenan}

Carrageenan content of Kappphycus striatum seaweed obtained during this study ranged from 43.50 - 80.63\% (Table 2) with an average of $63.62 \% \pm 12.54$. This content of carrageenan is relatively higher when compared to research conducted in several places such as the research conducted by (Marseno, W.D., Maria S. Medho., 2010) in East Nusa Tenggara which produced 34.98\% carrageenan. Research in the waters of Baruta, Sangia District, Wambulu, Buton Regency, Southeast Sulawesi, resulted in an carragenant content of $46.74 \%$ (Failu et al., 2016). The waters of Takalar Regency are worth 42.38 (Kurnia, 2017). Kemojan Karimunjawa waters, Jepara Regency worth 58.24 (Supriyantini et al., 2017) and 46.05 from Kertasari waters, West Sumbawa Regency (Arzani et al., 2020)

Measurement of the water content of Kappphycus striatum seaweed showed values varying between $9.75-24.91 \%$ (Table 2 ) with an average of $18.85 \% \pm 4.73$. Carrageenan has the ability to bind water (Gani et al., 2014) so that Kappphycus striatum seaweed obtained from the study site has a high water content.

Table 2. Results of measurement of the quantity and quality of Kappphycus striatum . seaweed carrageenan 


\begin{tabular}{|l|r|r|r|}
\hline Station & \multicolumn{1}{|l|}{$\begin{array}{l}\text { Carrageenan } \\
\text { content }(\%)\end{array}$} & $\begin{array}{l}\text { Water } \\
\text { content }(\%)\end{array}$ & \multicolumn{1}{l|}{$\begin{array}{l}\text { Ash content } \\
(\%)\end{array}$} \\
\hline Station 1.1 & 55.1 & 22.2 & 26.58 \\
\hline Station 1.2 & 74.38 & 18.01 & 36.05 \\
\hline Station 2.1 & 43.5 & 9.75 & 29.14 \\
\hline Station 2.2 & 69.58 & 18.03 & 24.75 \\
\hline Station 3.1 & 58.52 & 20.2 & 26.16 \\
\hline Station 3.2 & 80.63 & 24.91 & 24.67 \\
\hline
\end{tabular}

While the ash content of seaweed Kappphycus striatum in this study had a value of $24.67-36.05 \% \quad$ (Table 2) with an average of $27.89 \% \pm 3.94$. The high ash content shows that the mineral content in the seaweed produced in this area is also high (Ismal. Z et al., 2018) (Wenno et al., 2012). The ash content found in this study met the requirements of the FCC (Food Chemical Codex) of 18-40 and FAO (Food and Agricultural Organization) of 15-40 (Ega et al., 2016) and (Wulandari et al., 2019).

\subsection{The Effect of Oceanographic Factors on the Quantity and Quality of Carrageenan}

The results of Pearson's Simple Linear Correlation analysis at 95\% significance (Table 3) show that the quantity of carrageenan is positively correlated with turbidity, phosphate, current velocity and temperature and negatively correlated with $\mathrm{pH}$, nitrate, dissolved oxygen and salinity.

The increase in turbidity has an indirect effect on the increase in carrageenan. Turbidity has an impact on determining the amount of sunlight that enters the water layer (Abdul Majid, Nunik Cokrowati, 2016). With reduced sun intensity, seaweed is very susceptible to damage, so seaweed produces more carrageenan. Carrageenan is a class of galactan polysaccharides which are the intercellular matrix material in red seaweed or marine algae from the Rhodophyta class. Carrageenan in seaweed has a function as a hydrophilic structure. Flexible carrageenan can accommodate the speed of water currents and wave movements in the water (Prihastuti \& Abdassah, 2019) so that seaweed is not easily damaged.

Table 3. Results of Pearson's Simple Linear Correlation of Oceanographic Factors on Carrageenan Quantity and Quality

\begin{tabular}{|c|c|c|c|c|c|c|c|c|}
\hline \multicolumn{9}{|c|}{ Correlations } \\
\hline & pH & $\begin{array}{l}\text { Turbidity } \\
\text { (NTU) }\end{array}$ & $\begin{array}{l}\text { Dissolved } \\
\text { oxygen } \\
(\mathrm{mg} / \mathrm{L})\end{array}$ & $\begin{array}{l}\text { Salinity } \\
(\%)\end{array}$ & $\begin{array}{l}\text { Current } \\
\text { velocity } \\
(\mathrm{cm} / \mathrm{s})\end{array}$ & $\begin{array}{l}\text { Temperature } \\
\left({ }^{\circ} \mathrm{C}\right)\end{array}$ & $\begin{array}{l}\text { Phophate } \\
\text { (mg/L) }\end{array}$ & $\begin{array}{l}\text { Nitrate } \\
(\mathrm{mg} / \mathrm{L})\end{array}$ \\
\hline $\begin{array}{l}\text { Carragenan } \\
\text { content }\end{array}$ & -0.67 & 0.37 & -0.389 & -0.129 & 0.058 & 0.44 & 0.204 & $-.890^{*}$ \\
\hline $\begin{array}{l}\text { Water } \\
\text { content }\end{array}$ & 0.186 & 0.601 & $-.881^{*}$ & -0.448 & 0.285 & $.908^{*}$ & -0.309 & -0.271 \\
\hline Ash content & -0.795 & -0.442 & 0.032 & 0.048 & -0.499 & -0.544 & -0.403 & -0.044 \\
\hline
\end{tabular}

The presence of phosphate will have an effect on increasing plant activity for metabolic processes (Abdul Majid, Nunik Cokrowati, 2016). The abundance of phosphorus can stimulate the growth and rate of photosynthesis of some algae, as well as increase the production of carrageenan (Parenrengi et al., 2020).

The speed of the current affects the seaweed because the seaweed will affect the organisms in obtaining nutrients through the flow of water that is created at the time of the movement of the current. The movement of the water will carry nutrients and at the same time wash the dirt that sticks to the seaweed thallus. (Damayanti et al., 2019). So it can be said that the movement of water through water currents plays a very important role in obtaining nutrients for seaweed because currents play an important role in providing nutrients in the waters.

Temperature is known to affect several physiological functions that occur in seaweed including photosynthesis, respiration, metabolism, growth and reproduction (Ramdhan et al., 2018). Kappaphycus striatum variant sacol undergoes thallus decay at water temperatures below $24^{\circ} \mathrm{C}$ (Mairh et al., 1986).

Meanwhile the quality of carrageenan in the form of water content and ash content is also influenced by oceanographic parameters (Table 3). Water content testing aims to determine how much water content in carrageenan. The value of the water content of seaweed is related to the content of carrageenan contained by the seaweed. Carrageenan is a compound that has the ability to bind water. Carrageenan polymer chains will form a double helix that is wrapped around each other. This polymer chain can trap free water, so the higher the concentration of carrageenan, the more water bound by carrageenan (Gani et al., 2014) 
Another quality of carrageenan is ash content. Calculation of ash content is intended to determine the general mineral content contained in carrageenan (Wenno et al., 2012) or is an analysis carried out to evaluate the nutritional value of a food ingredient (Ismal. $\mathrm{Z}$ et al., 2018). The higher the ash content of a food, the greater the amount of minerals contained in the food (Wenno et al., 2012). The ash content of seaweed cultivated in Tadui Hamlet is supported by mangrove land that is still maintained around the cultivation area where the minerals needed by seaweed are obtained from mangrove litter which is available in large quantities. These minerals are used for seaweed metabolism processes including the formation of carrageenan.

In addition, the condition of the waters in Tadui Hamlet is still relatively good with the lack of human activities that can cause pollution to the waters in this area. Pollutants can come from domestic waste. The presence of domestic waste in water areas is characterized by the presence of nitrate $\left(\mathrm{NO}_{3}\right)$ and phosphate $\left(\mathrm{PO}_{4}\right)$ which exceeds the quality standard (Sujarwo \& Fitriyanny, 2016)

\subsection{Aquatic Environment Characteristic Parameters}

The results of the Principal Component Analysis (Figure 2), show that the carragenan content, water content and turbidity in the same plot (Plot 1). Meanwhile, ash content, salinity and current velocity are in the same plot (Plot 2). Then, phosphate, nitrate, $\mathrm{pH}$ and water temperature are in the same plot (Plot 3).

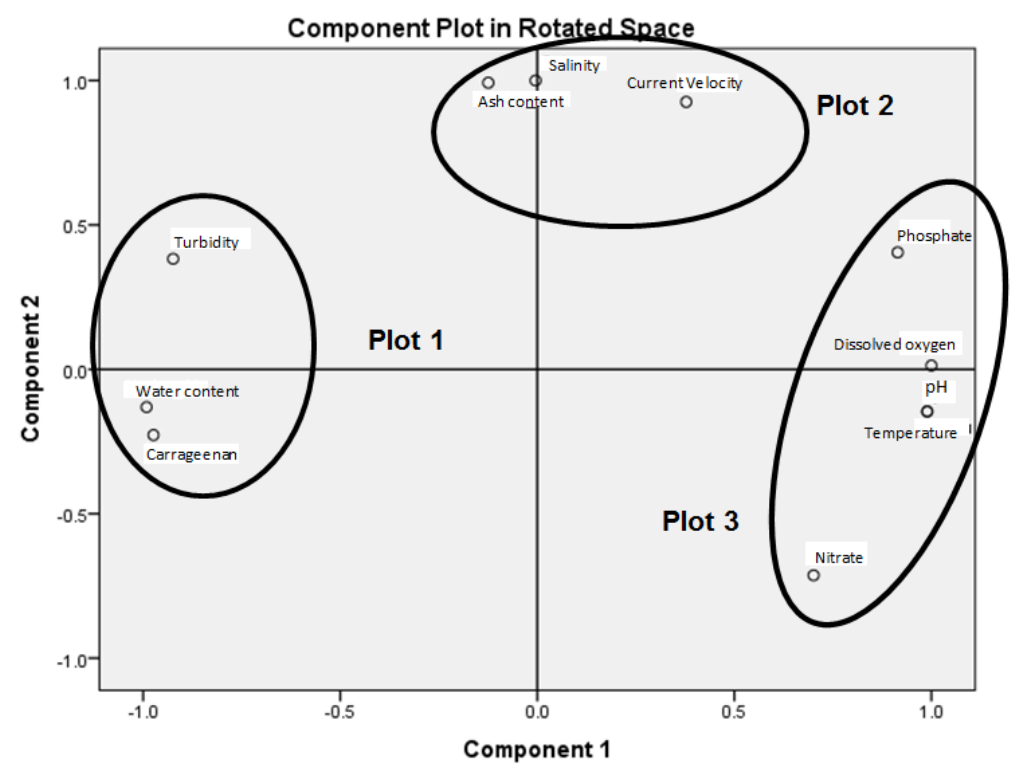

Figure 2. Principal Component Analysis plot results

Plot 1 shows that carrageenan content, water content have high values, and increased turbidity. Plot 2 is a parameter that has wide fluctuations for example salinity which has a value of $10 \%-33 \%$. While plot 3 is a parameter with a relatively constant value so that it gives an insignificant contribution value to the quality and quantity of carrageenan in this study

\section{Conclucion}

Based on the analysis of the quantity and quality of carrageenan, it can be concluded that the quantity of carrageenan is positively correlated with turbidity, phosphate, current velocity and temperature and negatively correlated with $\mathrm{pH}$, nitrate, dissolved oxygen and salinity.

Principal Component Analysis analysis produces 3 plots that affect the quality and quantity of carrageenan, namely plot 1 consists of carragenan content, water content and turbidity Plot 2 consists of ash content, salinity and flow velocity and plot 3 consists of Phosphate, Nitrate, $\mathrm{pH}$ and Temperature waters.

\section{Acknowledgements}

We are grateful to The West Sulawesi Provincial Government which has provided financial support through the Masters Program Scholarship for Civil Servant in the Scope of the West Sulawesi Provincial Government in 2019 - 2021, gratitude for Randi for his assistance in field data collection.

\section{References}

Abdul Majid, Nunik Cokrowati, N. D. (2016). Pertumbuhan Rumput Laut (Eucheuma cottonii) Pada Kedalaman Yang Berbeda Di Teluk Ekas, Kecamatan Jerowaru, Lombok Timur.

Adipu, Y., Lumenta, C., \& Sinjal, H. J. (2013). Kesesuaian Lahan Budidaya Laut Di Perairan Kabupaten Bolaang Mongondow Selatan, Sulawesi Utara. Jurnal This publication is licensed under Creative Commons Attribution CC BY. 
ISSN 2250-3153

Perikanan Dan Kelautan Tropis, 9(1), 19. https://doi.org/10.35800/jpkt.9.1.2013.3448

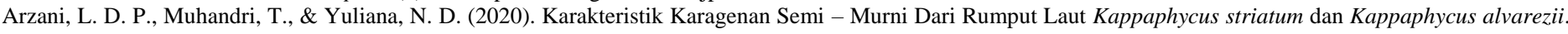
Jurnal Teknologi Dan Industri Pangan, 31(2), 95-102. https://doi.org/10.6066/jtip.2020.31.2.95

Aslan, L. M. (1998). Budidaya Rumput Laut. Penerbit Kanisius Yogyakarta.

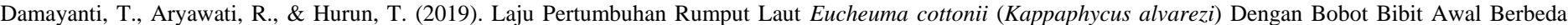
Menggunakan Metode Rakit Apung Dan Long Line Di Perairan Teluk Hurun, Lampung. Maspari Journal, 11(October 2017), 17-22.

Effendi, H. (2003). Telaah Kualitas Air Bagi Pengelolaan Sumber Daya dan Lingkungan Perairan. Kanisius Yogyakarta.

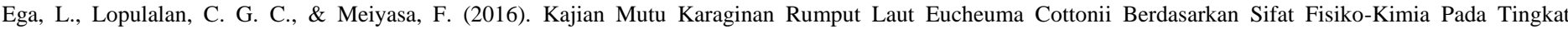
Konsentrasi Kalium Hidroksida (Koh) Yang Berbeda. Jurnal Aplikasi Teknologi Pangan, 5(2). https://doi.org/10.17728/jatp.169

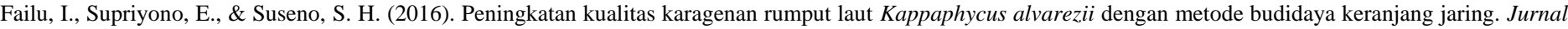
Akuakultur Indonesia, 15(2), 124. https://doi.org/10.19027/jai.15.2.124-131

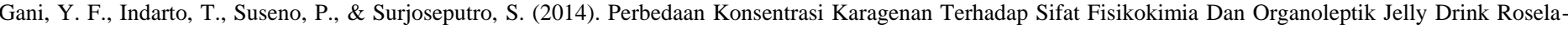
Sirsak. Journal of Food Technology and Nutrition, 13(2), 87-93.

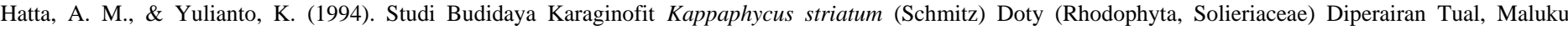
Tenggara. Periran Maluku Dan Sekitarnya, 6, 57-66.

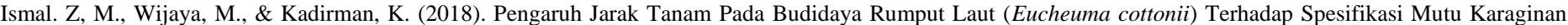
Jurnal Pendidikan Teknologi Pertanian, 4, 242-249. https://doi.org/10.26858/jptp.v4i0.7128

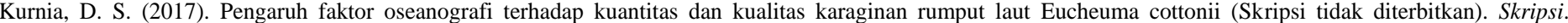
https://core.ac.uk/download/pdf/83870776

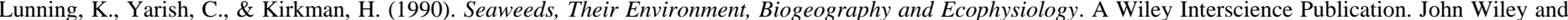
Sons Inc. New York.

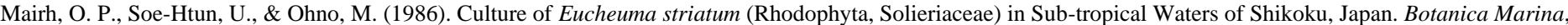
29(2), 185-192. https://doi.org/10.1515/botm.1986.29.2.185

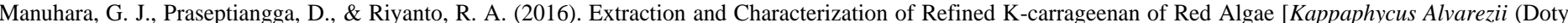
ex P.C. Silva, 1996)] Originated from Karimun Jawa Islands. Aquatic Procedia, 7, 106-111. https://doi.org/10.1016/j.aqpro.2016.07.014

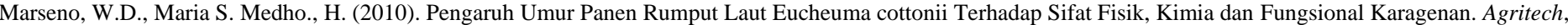
30(4), 8961.djagal@ugm.ac.id

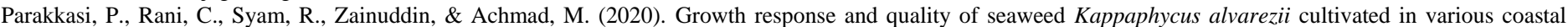
ecosystems in the waters of west Sulawesi, Indonesia. AACL Bioflux, 13(2), 627-639.

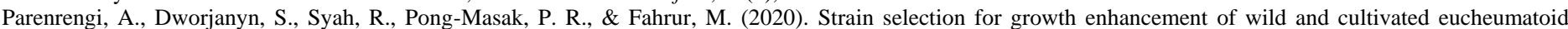
seaweed species in Indonesia. Sains Malaysiana, 49(10), 2453-2464. https://doi.org/10.17576/jsm-2020-4910-11

Parenrengi, A., \& Sulaeman. (2007). Mengenal Rumput Laut, Kappaphycus alvarezii. In Media Akuakultur (Vol. 2, Issue 1, pp. 142-146).

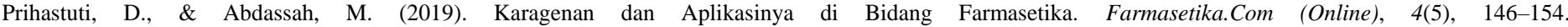
https://doi.org/10.24198/farmasetika.v4i5.23066

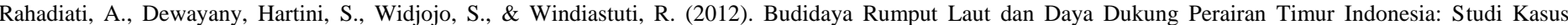
Kabupaten Konawe Selatan. Globe, 14(2), 178-186.

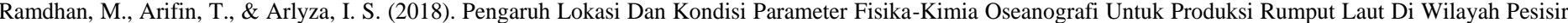
Kabupaten Takalar, Sulawesi Selatan Effect of Location and Conditions of Physic-Chemical Oceanography Parameters on the Production of Seaweed in T. Jurnal Kelautan Nasional, 13(3), 163-172.

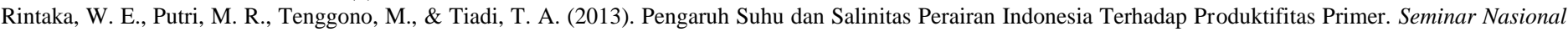
Tahunan X Hasil Penelitian Kelautan Dan Perikanan, August, 1-9.

SIPPO, O. P. (2017). Carrageenan and Agar Indonesa, Beyond The Land of Cottonii and Gracilaria. Swiss Import Promotion Programme.

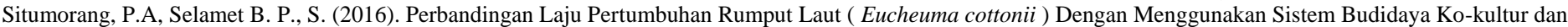
Monokultur di Perairan Pantai Geger, Nusa Dua , Bali. Journal of Aquakulture Management and Techonology, 5(1), $146-154$.

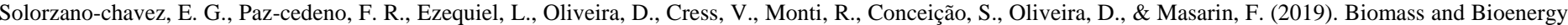
Evaluation of the Kappaphycus alvarezii growth under di ff erent environmental conditions and e ffi ciency of the enzymatic hydrolysis of the residue generated in the carrageenan processing. Biomass and Bioenergy, 127(May), 105254. https://doi.org/10.1016/j.biombioe.2019.105254

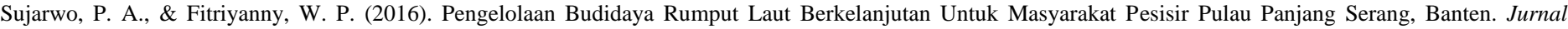
Kebijakan Sosial Ekonomi Kelautan Dan Perikanan, 6(2), 123. https://doi.org/10.15578/jksekp.v6i2.3326

Sulbar, D. (2018). Profil Potensi Usaha dan Peluang Investasi. Dinas Kelautan dan Perikanan Provinsi Sulawesi Barat Mamuju.

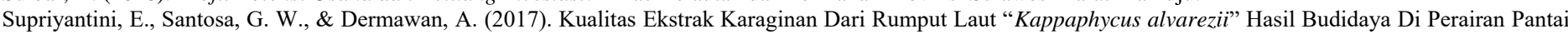
Kartini Dan Pulau Kemojan Karimunjawa Kabupaten Jepara. Buletin Oseanografi Marina, 6(2), 88. https://doi.org/10.14710/buloma.v6i2.16556

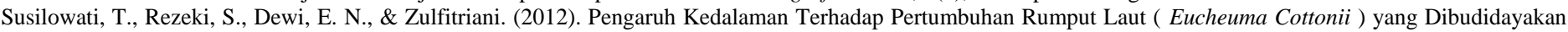
Dengan Metode Longline. Saintek Perikanan, 8(1), 7-12.

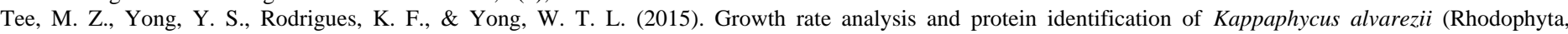
Gigartinales) under $\mathrm{pH}$ induced stress culture. In Aquaculture Reports (Vol. 2, pp. 112-116). https://doi.org/10.1016/j.aqrep.2015.09.001

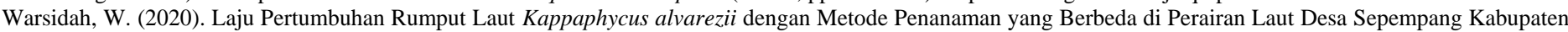
Natuna Seaweed. Jurnal Laut Khatulistiwa, 3(August), 14-22.

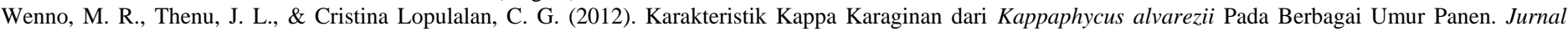
Pascapanen Dan Bioteknologi Kelautan Dan Perikanan, 7(1), 61. https://doi.org/10.15578/jpbkp.v7i1.69

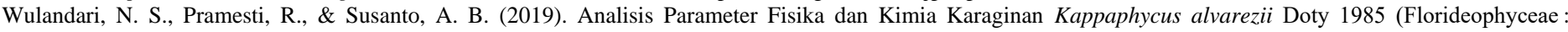
Solieriaceae) dengan Variasi Ekstraksi dari Perairan Bluto. Journal of Marine Research, 8(4), 409-415. 